\title{
On the links between mathematics education and democracy: A literature review
}

\begin{abstract}
Authors:
Mario Sánchez Aguilar ${ }^{1}$

Juan Gabriel Molina Zavaleta ${ }^{1}$

Affiliations:

${ }^{1}$ Mathematics Education

Department, National

Polytechnic Institute, Mexico

Correspondence to:

Mario Sánchez Aguilar

Email:

marios@ruc.dk

\section{Postal address:}

National Polytechnic

Institute, Legaria 694,

Colonia Irrigación, C.P. 11500,

D.F., Mexico

Dates:

Received: 15 Mar. 2012

Accepted: 04 Nov. 2012

Published: 03 Dec. 2012

How to cite this article: Aguilar, M.S., \& Zavaleta, J.G.M. (2012). On the links between mathematics education and democracy: A literature review. Pythagoras, 33(2), Art. \#164, 15 pages. http://dx.doi.org/10.4102/ pythagoras.v33i2.164
\end{abstract}

(C) 2012. The Authors. Licensee: AOSIS OpenJournals. This work is licensed under the Creative Commons Attribution License.
This article reports the results of a literature review focused on identifying the links between mathematics education and democracy. The review is based on the analysis of a collection of manuscripts produced in different regions of the world. The analysis of these articles focuses on six aspects, namely, (1) definitions of democracy used in these texts, (2) identified links between mathematics education and democracy, (3) suggested strategies to foster a democratic competence in mathematics students (4) tensions and difficulties inherent in mathematical education for democracy, (5) the fundamental role of the teacher in the implementation of democratic education and (6) selected criticisms of mathematical education for democracy. The main contributions of this article are to provide the reader with an overview of the literature related to mathematics education and democracy, and to highlight some of the theoretical and empirical topics that are necessary to further development within this research area.

\section{Introduction}

The connection between democracy and mathematics education is not a new topic in the field of mathematics education research. These connections have been discussed in our field for over 20 years (see e.g. D'Ambrosio, 1990; Skovsmose, 1990). So why is it important to do a literature review on mathematics education and democracy now? We think that there are at least two reasons for this.

Firstly, although some authors, such as Gutiérrez (2010), claim that our field is currently experiencing a 'sociopolitical turn' (that is, a growing awareness of the need to consider the political, power and identity issues associated with mathematics education), our field is still dominated by views that consider the relationship between the teacher, the students and the mathematical content as the main space of inquiry (Pais \& Valero, 2012; Valero, 2007). Similarly, amongst practitioners there exists a limited view of the role that mathematics education can play in forming critical citizens able to live in and sustain democratic societies. Thus we believe that a literature review addressing the links between mathematics education and democracy may help to challenge and contest these perspectives, and increase awareness about the need to widen the area of inquiry that has been favoured traditionally.

Secondly, although discussion of the connections between mathematics education and democracy is not new, it has branched out into related topics such as equity and social justice, indicating that this discourse is far from complete. In fact, there are several research topics related to mathematics education and democracy that need further exploration. One contribution of this literature review is to highlight some of the theoretical and empirical research that is necessary to further develop this field.

\section{Aim and structure of the article}

The literature related to mathematics education and democracy is extensive. This article consists of a review of that specialised literature, presenting it in a summarised and organised way. This review is aimed at readers who are unfamiliar with this research area, and would like an introductory overview of it. The review is based on the analysis of a collection of texts produced in different regions of the world. The analysis of these articles is focused on six aspects:

1. The definitions of democracy that are used.

2. Identified links between mathematics education and democracy.

3. Suggested strategies to foster democratic competence in mathematics students.

4. Tensions and difficulties inherent in mathematical education for democracy.

5. The fundamental role of the teacher in the implementation of democratic education.

6. Selected criticisms of mathematical education for democracy.

The review concludes with a discussion of the literature analysed, where we indicate some of the theoretical and empirical research that is required to further develop this area of research. 


\section{Method}

This method used to select the texts for this review was guided and defined by two key questions, (1) Where should we look? and (2) What should we look for? Next we describe how these two questions were operationalised.

\section{Where should we look?}

From the beginning we wanted to develop a 'democratic review' including different voices and views on the relationship between mathematics education and democracy. We tried to do this by performing a literature search that included not only international journals, but also regional journals with influence and authority in different regions of the world. In our review we also included proceedings of some international conferences as well as selected books on mathematics education research. These literature sources were organised into three layers, described in more detail below.

\section{Layer 1 - Journals}

In this layer we included international and regional journals. In each case we selected the journals that we consider to be the most influential and representative. The regional journals were divided into the regions of Latin America, North America, Australasia, Europe and Africa. It is important to clarify that, although these journals are produced in particular regions of the world, it is likely that at least some of them may not represent the thinking of the researchers within the geographical areas where they are produced, simply because they may contain articles written by authors from outside that region. This is particularly true for some of the journals included from Europe and North America.

This review included five journals in the 'international' category: Educational Studies in Mathematics, ZDM: The International Journal on Mathematics Education, For the Learning of Mathematics, International Journal of Science and Mathematics Education and International Journal of Mathematical Education in Science and Technology.

The Latin American journals included in this review were: Educación Matemática, Revista Latinoamericana de Investigación en Matemática Educativa and Bolema: Boletim de Educação Matemática.

We also included two North American journals, namely Journal for Research in Mathematics Education and The Journal of Mathematical Behavior.

The Australasian region was represented in this review by the journal Mathematics Education Research Journal.

For the European region we selected the journals Research in Mathematics Education and Philosophy of Mathematics Education Journal.

Finally, we included the journal Pythagoras to represent the African region.

\section{Layer 2 - Conference proceedings}

In this layer we included proceedings of international conferences that were freely available on the Internet. We examined the most recent proceedings of the International Congress on Mathematical Education (ICME) and of the Congress of European Research in Mathematics Education (CERME). We also included the proceedings of the international conference Mathematics Education and Society (MES). In particular, we reviewed the proceedings of the ICME 10 (retrieved from http://www.icme10.dk/) and the papers associated with the discussion groups and topic study groups of the ICME 11 (retrieved from http://dg.icme11.org/ and http://tsg. icme11.org/). We also reviewed the proceedings of the CERME 7 (retrieved from http://www.erme.unito.it/doc/ cerme7/CERME7.pdf) and the CERME 6 (retrieved from http:/ /ife.ens-lyon.fr/editions / editions-electroniques / cerme6/). In the case of the proceedings of the MES conference, we reviewed the proceedings of the conference MES 1 (retrieved form http://www.nottingham.ac.uk/ csme/meas/measproc.html), MES 2 (retrieved from http:/ / nonio.fc.ul.pt/mes2/), MES 3 (retrieved from http://mes3. learning.aau.dk/), MES 5 (retrieved from http://pure.ltu. se/portal/files/2376308/Proceedings_MES5.pdf) and MES 6 (retrieved from http://www.ewi-psy.fu-berlin.de/en/v/ mes6/proceedings/index.html). The proceedings of the conference MES 4 were not included in the review because they were not freely available on the Internet.

Due to its importance and influence, we would have liked to include in our review the proceedings of the conferences organised by the International Group for the Psychology of Mathematics Education (PME). However, these proceedings are not available online and they were not accessible through the library of our university; hence, they could not be included in this review. This can be considered as one of our review's limitations.

\section{Layer 3 - Books}

In this layer we included books on mathematics education research. These books were identified though a study of the bibliographies of the selected articles contained in the first layer. As we went through the lists of references used in these articles, we noticed that certain books were cited frequently; after examining them directly, we decided which ones to include in this third layer of this review.

\section{What should we look for?}

The layers just described illustrate where we looked when searching the materials used in this review. What we want to do now is to clarify how we selected the sources used in this review.

The documents selected for the review complied with the following condition: in the title, abstract, keywords or the body of the paper they used the key term 'democracy', or related terms such as 'democratic' and 'democratisation'. We set this condition to try to ensure that the selected texts would address the relationship between mathematics education 
and democracy. However, we are aware that this condition may have excluded some sources that discuss political issues related to democracy, such as equity and social justice, but fail to explicitly use the term 'democracy'. This should be considered as another limitation of our review.

We used search engines to find key terms within the documents. For example, for the articles contained in Layer 1 we used the Web-based search engines included in the Web pages of the journals. These tools allowed us to quickly locate relevant articles contained in large collections of documents. For the documents contained in Layer 2 and Layer 3, we located the key terms by using the 'search' function of the PDF reader program. For some documents in Layer 3 it was necessary to locate the key terms manually.

\section{What was excluded from the review?}

Not all the materials identified in Layer 1, Layer 2 and Layer 3 were included in our literature review. Next we explain the various reasons for exclusion.

It is important to note that not all the documents containing a key term such as 'democracy' or 'democratic' were relevant to the review. Consider, for example, an article by Hanna and Sidoli (2002) where the phrase 'mathematical education and democracy' appears in the body of the article. Within the article, however, the phrase is used to refer to the title of an article written by Skovsmose (1990). In fact, Hanna and Sidoli (2002) do not address the relationship between democracy and mathematics education at all, but rather focus on providing a statistical profile of articles published in the journal Educational Studies in Mathematics. Another category of articles that was not considered in this review was those that mentioned a possible relationship between mathematics education and democracy, but only superficially. For example, there were texts claiming that mathematics is important for the education of citizens, but the reasons why mathematics is important were not clarified.

We considered only materials written either in Spanish, Portuguese or English; as a result, articles written in other languages were excluded, as was the case for three articles from the special issues on mathematics education and democracy in the journal ZDM: The International Journal on Mathematics Education, issues 30(6) and 31(1), which were written in German.

The Philosophy of Mathematics Education Journal was not reviewed in its entirety. We only surveyed the two special issues on social justice, June and September 2007, and the special issue on critical mathematics education, October 2010. Since our literature review was essentially a Web-based review, there are other journals that were not fully scrutinised because not all their issues are available online. This is the case with the journals Pythagoras, Educación Matemática, Bolema: Boletim de Educação Matemática, ZDM: The International Journal on Mathematics Education, Journal for Research in Mathematics Education and The Journal of Mathematical Behavior.

Table 1, Table 2 and Table 3 show an overview of the references consulted for the development of the review. Readers interested in the details of the consulted references (title, journal, volume, etc.) can refer to Appendix 1, located at the end of this review.

After selecting the texts, we posed two questions to guide our detailed analysis:

1. What are the links between mathematics education and democracy that are identified in these texts?

2. What proposals or strategies do they recommend to strengthen these linkages?

Whilst reading the materials, we also realised that it was necessary to focus on other relevant aspects of the mathematics education-democracy relationship addressed in some of the texts. For example, what tensions or difficulties are encountered in implementing mathematical education for democracy, or the centrality of the role of teachers in the implementation of democratic education. Thus, we decided to widen our focus to include the six aspects listed in the explanation of the structure of this article. In the remainder of the article we will report the results obtained by focusing our review on these six aspects. We will end this article discussing some of the topics that need further research in order to develop this area of research and acknowledge the limitations of this review.

TABLE 1: Overview of the references consulted for the development of the literature review: Layer 1 - Journals.

\begin{tabular}{|c|c|c|c|}
\hline Region & Journal & Reviewed period & No. papers \\
\hline Africa & Pythagoras & Issue 59,2004 - Volume 33, 2012 & 1 \\
\hline Australasia & Mathematics Education Research Journal & Volume 1, 1989 - Volume 24, 2012 & 2 \\
\hline \multirow[t]{2}{*}{ Europe } & Research in Mathematics Education & Volume 1, 1999 - Volume 14, 2012 & 0 \\
\hline & Philosophy of Mathematics Education Journal & Numbers 20,21 and 25 & 7 \\
\hline \multirow[t]{5}{*}{ International } & Educational Studies in Mathematics & Volume 1, 1968 - Volume 80, 2012 & 6 \\
\hline & International Journal of Science and Mathematics Education & Volume 1, 2003 - Volume 10, 2012 & 0 \\
\hline & ZDM: The International Journal on Mathematics Education & Volume 29, 1997 - Volume 44, 2012 & 13 \\
\hline & For the Learning of Mathematics & Volume 1, 1981 - Volume 32, 2012 & 3 \\
\hline & International Journal of Mathematical Education in Science and Technology & Volume 1, 1970 - Volume 43, 2012 & 3 \\
\hline \multirow[t]{3}{*}{ Latin America } & Revista Latinoamericana de Investigación en Matemática Educativa & Volume 0, 1997 - Volume 15, 2012 & 0 \\
\hline & Bolema: Boletim de Educação Matemática & Volume 1, 1985 - Volume 46, 2012 & 4 \\
\hline & Educación Matemática & Volume 15, 2003 - Volume 23, 2011 & 0 \\
\hline \multirow[t]{2}{*}{ North America } & Journal for Research in Mathematics Education & Volume 28, 1997 - Volume 43, 2012 & 2 \\
\hline & The Journal of Mathematical Behavior & Volume 13, 1994 - Volume 31, 2012 & 2 \\
\hline
\end{tabular}


TABLE 2: Overview of the references consulted for the development of the literature review: Layer 2 - Conference proceedings.

\begin{tabular}{lc}
\hline Conference & No. papers \\
\hline ICME 11 & 1 \\
ICME 10 & 1 \\
CERME 7 & 1 \\
CERME 6 & 1 \\
MES1 & 3 \\
MES2 & 2 \\
MES3 & 6 \\
MES5 & 1 \\
MES6 & 2 \\
\hline
\end{tabular}

ICME, International Congress on Mathematical Education; CERME, Congress of European Research in Mathematics Education; MES, Mathematics Education and Society.

TABLE 3: Overview of the references consulted for the development of the literature review: Layer 3 - Books.

\begin{tabular}{lc}
\hline Books & No. chapters \\
\hline $\begin{array}{l}\text { International perspectives on social justice in mathematics } \\
\text { education }\end{array}$ & 1 \\
$\begin{array}{l}\text { Quantitative literacy: Why numeracy matters for schools and colleges } \\
\text { Mathematics and democracy: The case for quantitative literacy }\end{array}$ & 1 \\
Sociocultural research on mathematics education & 1 \\
Towards a philosophy of critical mathematics education & 1 \\
Handbook of international research in mathematics education & 3 \\
\hline
\end{tabular}

\section{Definitions of democracy used in these texts}

Different definitions of democracy were found in the texts analysed. Skovsmose and Valero (2001) affirm that this richness of definitions suggests that the open nature of democracy is such that a precise definition of the concept is not possible. However, we think is important to try to identify the interpretation of democracy that each author adopts since the ideas, concepts and proposals that they present are usually related to their own interpretation of democracy.

One of the most elaborate definitions of democracy is that of Murillo and Valero (1996), cited in Valero (1999), in which democracy is interpreted as an ideal form of social organisation with four dimensions:

Democracy can be defined as an ideal way social organization establishes a series of political, juridical, economic and cultural values, norms and behaviors aiming at providing a better living for the whole population of a given state. This definition highlights a conception of democracy not as an actual reality, but as a goal to reach. ... This definition also considers four different dimensions of democracy. The political dimension includes the series of procedures to form governments by means of regular, free elections as the corner stone of representative democracy. The juridical dimension sets and protects the different basic legal human rights and duties. The economic dimension deals with the material conditions of living and the organization of the economy by the state. And the socio-cultural dimension which considers the space where democratic values are embedded and embodied in people's interactions. (p. 20, [author's own emphasis])

In this article we use this definition of democracy as a framework that allows us to present, in an orderly manner, other explicit definitions of democracy located in the articles included in the review. We decided to use this definition because it offers an overarching characterisation of democracy covering the different dimensions of democracy that are identified in other definitions.

\section{The political dimension of democracy}

Authors such as Woodrow (1997) and Almeida (2010) refer to the political dimension of democracy; that is, the type of democracy where citizens elect their representatives to participate in discussions about public affairs and make decisions related to those public affairs. Representatives are elected through free elections in which citizens exercise their right to vote. This interpretation of democracy assumes that citizens do not directly participate in the discussion of public affairs, but they do so through the representatives of their choice. Skovsmose (1994) criticises this interpretation of democracy because it puts the election of the government at the centre of the discussion, and makes other conditions or dimensions of democracy irrelevant.

Skovsmose (1998) proposes an alternative interpretation of democracy, inspired by the concept of direct democracy. Here democracy is conceptualised as a form of political democracy in which citizens participate directly in the discussion of public affairs. This position may seem impractical if we think of a state, but Skovsmose conceives the application of this type of democracy in all types of institutions, such as workplaces, schools and classrooms. It is in these kinds of institutions that Skovsmose's position seems clearly applicable and feasible. Furthermore, this conception of democracy puts the type of skills that a citizen must possess in order to fully participate in the public discourse at the centre of the discussion. This point will be addressed later in the review, when we discuss the links between mathematics education and democracy.

\section{The juridical dimension of democracy}

Respect for the rights and freedoms of individuals is another element included in some definitions of democracy. For example, Harris (1998) mentions that a characteristic of democracies is that they are social formations where people have largely equal rights as citizens. Woodrow (1997) and Almeida (2010) refer to democracy as concerned with the protection of the individual's human rights and freedoms within society. Such freedoms include freedom of speech, freedom to work, freedom from hunger, freedom from oppression and freedom to worship.

\section{The economic dimension of democracy}

Skovsmose (1998) points out that democracy is subject to the fulfilment of certain conditions. One of these conditions is the fair distribution of goods; in other words, democracy is not possible in a context where material goods are unevenly distributed. Although D'Ambrosio (2003) does not mention an explicit definition of democracy, he also emphasises the importance of sharing the cultural and natural goods amongst all human beings in order to ensure the survival and intellectual enhancement in a democratic society.

\section{The socio-cultural dimension of democracy}

Democracy not only refers to the fair distribution of goods, equal rights for citizens and the free election of 
representatives. It also refers to a type of social organisation that can accommodate different views and ways of thinking. Hannaford (1998) pays special attention to this aspect of democracy, referring to two types of democracy. The first is a single-minded democracy, where people's values and ways of thinking are homogeneous. In this kind of democracy there is no room for people with alternative ways of thinking. The second kind of democracy is that in which there are almost as many ways of thinking as there are people. Hannaford claims that the latter type of democracy is slower and seems less efficient; however, history has shown that in the long term it is more efficient than depending on only one idea.

As the above discussion shows, the concept of democracy is multidimensional; that is, it is a concept that refers to freedoms, rights, obligations, the distribution of material and cultural goods, and respect for diversity of ideas and ways of thinking. The question now is: What are the links between mathematics education and democracy? In the following section of the article we will present the links that we have identified through the literature review.

\section{Links between mathematics education and democracy}

As noted by De Mattos and Batarce (2010) and Valero (1999), the term 'mathematics education' has at least two meanings. The first one refers to mathematics education as a field of research, whilst the second one refers to mathematics education as a set of practices associated with the teaching and learning of mathematics. Such practices are not confined to the classroom. As noted by Valero (1999), they include external educational practices that affect the learning and teaching of mathematics, such as curricular policymaking, mathematics textbook writing and pre-service and inservice education. In this section, where we address the links between mathematics education and democracy, we have adopted the second connotation. We have identified three links between mathematics education and democracy in our literature review.

Firstly, mathematics education can provide students with mathematical skills to critically analyse their social environment, and also to identify and evaluate the uses and misuses of mathematics in society. The second link relates to the fact that the mathematical education that students receive in a classroom can promote or inhibit values and attitudes that are essential to build and sustain democratic societies. The third link is the acknowledgment that mathematics education can function as a sort of social filter that restricts the opportunities for development and civic participation of some students.

\section{Link 1: Mathematics education as a provider of critical mathematical skills}

One idea that Skovsmose $(1990,1998)$ particularly highlights, but which is also mentioned by D'Ambrosio $(1990,2003)$ and Orrill (2001), is the pervasive role that mathematics plays in modern societies. As stated by D'Ambrosio (1990, p. 21), 'our life is regulated by mathematical indices.'

Mathematics is applied in economics, politics, marketing, administration, education, et cetera. Mathematics is an integral component of society. In fact, society is largely shaped by mathematics. Thus many decisions that are socially relevant may be strongly influenced by mathematical models and applications, for example which municipalities in a country are considered poor enough to receive additional financial aid from the state, how much an employee should produce in order to maintain their position within a company, or what level of pollution levels in a city should lead to a recommendation that the inhabitants avoid exercising outdoors. The important point here is that it would be difficult for citizens to assess whether these decisions are fair or appropriate if they have not received a proper mathematical education. In sum, a mathematical education helps citizens to identify how mathematics is being applied to support such decisions, and to reflect on the consequences, positive and negative, that this application can produce. In order to maintain a democratic society, it is important that citizens are capable of critically analysing such questions and their answers because if they are to understand the economic and juridical dimensions of democracy, for example how the economic resources are distributed in a country or the defence of labour and environmental rights, it is vital that they understand the mathematics underlying those decisions.

When we refer to the particular case of the application of mathematics in politics, we are addressing the connection between mathematics education and the political dimension of democracy. For example, Almeida (2010) remarks:

One of the ways that the government or elected representatives convince the citizens that their policies are the correct ones is by producing reports which include a mass of numerical and statistical data. There are many instances where this data is misleadingly summarised. (p. 13)

Along the same lines, Wagner and Davis (2010) assert:

As politicians and bureaucrats use numbers to claim objectivity, to mask their biases, and to legitimize their decisions, it could be said that the citizens, who have been enculturated in schools to put their trust in number, are being duped by number, not empowered to make informed decisions, and, of course, claims of objectivity are made by more people than politicians and bureaucrats. Children and adults need their number sense to be part of their critical sense. (p. 49)

These quotes illustrate the importance of having mathematically literate citizens, able to critically analyse the reports and statements issued by the politicians who govern them. A democracy without this kind of citizenry is a fragile democracy.

\section{Link 2: Mathematics education as a source of values and attitudes}

In the previous section we emphasised the importance of having mathematically educated citizens, able to critically analyse how mathematics is applied in their societies. 
However, an adequate mathematical education is not sufficient to produce critical citizens. A critical citizenry also requires the promulgation of democratic values and attitudes. Values like tolerance and respect for diversity, and attitudes about truth that demand the critical analysis of information. The second link between mathematics education and democracy identified in our review is the claim made by several authors that the mathematics classroom can be any place where, alongside mathematics learning, it is possible to transmit and acquire (perhaps subconsciously) both democratic and undemocratic values and attitudes. This link is closely related to the socio-cultural dimension of democracy, which refers to the social space where democratic values are produced. Bishop (2002) refers to the transmission of values in the mathematics classroom as follows:

\begin{abstract}
Underpinning any discussion about social justice and democratisation in mathematics education lies the issue of 'values'. This is problematic at the present time because we neither know what currently happens with values teaching in mathematics classrooms, or why, nor do we have any idea how potentially controllable such values teaching is by teachers. In addition, many mathematics teachers are not even aware that they are teaching any values when they teach mathematics. Changing that perception may prove to be one of the biggest hurdles to be overcome if we are to move to a more just mathematics education. (p. 1)
\end{abstract}

A key concept for understanding the process of transmission of values and attitudes is that of classroom absolutism. Skovsmose (1998) uses this concept and explains it as follows:

The phenomenon that communication between students and teacher is structured by the assumptions that mathematics (school mathematics) can be organised around exercises and questions which have one and only one correct answer, and that, ultimately, it is the teacher's job to make sure that mistakes are eliminated from the classroom. (p. 200)

Authors such as Valero (1999) and Almeida (2010) affirm that this type of classroom interaction creates authoritarian relations between teachers and students: relationships in which students learn to uncritically accept the claims and dictates of the authority.

Skovsmose (1990) argues that the nature of mathematics classroom interactions can teach the students to follow explicitly stated prescriptions. This process takes place through instructions such as 'Solve the equation ...', 'Find the length of ...', 'Calculate the value of ...' Skovsmose argues that these kinds of instructions have little to do with the actual processes of investigations, being more closely related to the instructions that characterise the routine work processes. Hence, Skovsmose suggests that this sort of mathematical education, more than producing critical citizens, prepares students to perform routine work and become part of the workforce.

In turn, Hannaford (1998) suggests that the teaching of mathematics in which students are taught that there is no room for mistakes and there is only one correct answer does not promote plurality and respect for the diversity of ideas.

\section{Link 3: Mathematics education as a social gatekeeper}

The third link that we have identified relates to the fact that mathematics education can function as a kind of social filter. It is a social filter in the sense that it not only restricts students' opportunities for development, but may even limit their civic participation. Several researchers acknowledge this situation (e.g. Amit \& Fried, 2002; Anderson \& Tate, 2008; Christiansen, 2006; Knijnik, 2002; Malloy, 2008; Skovsmose \& Valero, 2008). For instance, Thomas (2010), referring to the Australian situation, states:

Australia and some other nations risk becoming societies divided by access to mathematical knowledge. A minority will have access to high levels of mathematics and will be the highly paid professionals and leaders. The majority will have 'benchmark' levels of mathematics and will be poorly paid, often unemployed or underemployed, and in 'service' industries. This is not the basis for either a clever country or a democracy but it is the basis for a divided society. (p. 137)

Indeed, by preventing students' access to higher education, lack of a mathematics education limits students' opportunities for a professional career or finding a decent and well-paid job. In short, it decreases their chances of economic and social success. Skovsmose (1998) has even suggested that lack of a mathematics education may contribute to the growth in modern societies of a new lower class.

The lack of mathematics education can even limit people's participation in civic society. For example, when mathematics is used in political discussions of social problems, only those who understand the mathematics being used can criticise its use and participate in the discussion, effectively leaving citizens who lack such knowledge out of any deliberations. As noted by Christiansen (2008), 'the use of mathematics [in political discussions] may exclude someone from (feeling confident) taking part in the discussion' (p. 72). Johansen (2002) points out that even some politicians acknowledge that the lack of mathematical skills can be an impediment for citizens' participation in public debates and democratic processes.

Orrill $(2001)$ and Skovsmose $(1994,1998)$ go so far as to argue that the lack of such knowledge is a threat to democracy because people who are not mathematically literate cannot fully participate in civic life. Unless a population has such mathematical knowledge the potential criticism that may exercise social controls over society's leaders is threatened. In the words of Skovsmose (1994):

Democracy may be destroyed by a dictatorship which obstructs formal democratic procedures. ... Democracy can be undermined in ways other than by just neglecting rules of election. Democracy refers not only to formal, but also to material and ethical conditions and to possibilities for participation and reaction. In particular, democracy can be destroyed if a critical citizenship cannot brought into life. (p. 38)

\section{Strategies to foster a democratic competence in students}

The links between mathematics education and democracy are not only a matter of promulgating specific mathematical 
skills, but also a matter of promoting democratic values and attitudes needed to create the democratic competence (Skovsmose, 1990) necessary to apply and critically analyse the use of mathematics in society. How to promote such democratic competence in mathematics students, however, is the subject of much debate.

\section{Fostering critical mathematical skills}

The term critical mathematical skills refers to the mathematical knowledge that allows students to use mathematics to analyse social problems or to address issues relevant in their personal lives. Such critical mathematical skills enable students to identify and judge how mathematics is applied to address socially relevant issues, as well as to reflect on the consequences of their application.

One suggestion made by Almeida (2010), Christiansen (2008) and Moreira (2000) is that mathematics teaching should include activities that will encourage students to use mathematics as a 'thinking tool'. These activities can be used both to assist students in developing an understanding of mathematical tools and ideas, and to analyse social problems. For example, Christiansen (2008) asked preservice teachers to represent in different ways the share of land that Black people and White people in South Africa owned in 1981, and then to reflect on the impression given by each representation. Besides promoting a reflection on the different ways quantitative information may be represented, this activity also made these future teachers aware of the racial problems in South Africa. Moreira (2000) used similar methods to introduce students to mathematical applications that allow them to analyse various economic, political and social problems, such as trends in the number of people with AIDS, the impact of fishing policies on endangered species, and the advantages and disadvantages of adopting nuclear power as a source of energy.

Malloy (2008) in turn suggests that students should be confronted with moral issues that surround the uses mathematics:

\begin{abstract}
We must present them with problems that not only tackle issues that affect their communities, but also reveal the motivations and the hidden agenda (curriculum) in their world. When students use and apply mathematical knowledge in such situations, they are learning to think critically about world issues and their environment through mathematics. Through this process students will have an understanding of inequities in society, and will be able to critique the mathematical foundations of social situations. (p. 28)
\end{abstract}

Another suggestion, offered by Skovsmose (1990), is to promote critical mathematical skills through teaching mathematical modelling and applications in order to prepare students to identify and evaluate the applications of mathematics in society. However, as Skovsmose also points out:

It is not possible to develop a critical attitude towards the application of mathematics solely by improving the modelling capability of students. ... To develop a more critical attitude towards this model building we have not only to understand the mathematical construction of the model; we have also to know about its assumptions. We must be able to point out which economical ideas are hiding behind the curtain of mathematical formulas. (p. 112)

Thus Skovsmose suggests the use of empowering teachinglearning materials (that is, didactical activities) as a means for students to develop critical mathematical skills through the use of open teaching-learning materials whose main characteristics are that (1) the material has to do with a topic of subjective relevance for the students, (2) the material initiates a variety of activities, not pre-structured and fully fixed, and (3) several decisions have to be taken when involved in the teaching-learning process, which normally necessitate a discussion between teacher and students (Skovsmose, 1990, pp. 118-119).

Orrill (2001) goes even further and argues that we should avoid the compartmentalisation of the mathematical knowledge in the school curriculum. In other words, he argues that the teaching of mathematics should be spread across the curriculum. The logic behind this idea is that in real life mathematics is everywhere; it should not be isolated into a single subject. Skovsmose and Valero (2001) express the same idea this way:

There is also a need to consider that mathematical competencies do not operate in isolation outside school but as part of integrated units assembled in schooling. This implies interdisciplinarity among the school subjects as an important research issue. Competencies in one discipline interact - or counteract - with competencies developed in other disciplines. Even more, competencies development in a school setting interact - or counteract - with competencies formed and used outside the school. (p. 49)

\section{Fostering democratic values and attitudes}

Explicitly or implicitly, proposals to use mathematics to promote democratic values and attitudes require challenging traditional absolutism in the mathematics classroom. Such proposals aim both at modifying the kinds of interactions that occur between the teacher and the students, and at changing the mathematical activities that mediate such interactions.

A basic idea behind the promotion of democratic values and attitudes in students is the one proposed by Vithal (1999): that within the mathematics classroom it is possible for students to experience democratic life. In the mathematics classroom students can learn, amongst other things, to listen to others' ideas, to argue, to take decisions and to critically analyse arguments made by authorities (the mathematics teacher for example). Ernest (2002) also makes this point:

Teaching approaches should include discussions, permit conflict of opinions and views but with justifications offered, the challenging of the teacher as an ultimate source of knowledge (not in their role as classroom authority), the questioning of content and the negotiation of shared goals. (p. 6)

Skovsmose (1990) claims that it is essential to change the fixed and pre-structured mathematical activities within the 
classroom that characterise traditional mathematics teaching. He argues that the use of open materials (see description above) is compatible with the kind of investigative activities known as project work. He further posits that these kinds of mathematical activities give students more power to make decisions about what to study and how to study it. It also covers the mathematics lessons with uncertainty because it is difficult to predict how students' projects will evolve. In other words, this approach fundamentally changes the roles and the power relations between teachers and students.

Hannaford (1998) makes another important proposal to promote dialogue and negotiation in the mathematics classroom. He argues that students should be taught to listen, to think, to argue effectively, and to respect others because democracy depends on those values. In a similar vein, Almeida (2010) recommends the use of (informal) mathematical proof as a means to introduce students to a culture of interrogating explanations. Students should be invited to consider the explanations provided to them, and to question their level of plausibility. It is especially important for them to learn to look critically at the information and explanations provided by the teacher. According to Almeida (2010), if students uncritically accept the information that teachers provide simply because they are authority figures, then it is likely that as citizens they will tend to accept uncritically the information and proposals politicians provide. Vithal (1999) similarly envisages the mathematics classroom as a democratic microsociety where the students can learn to both live together with and talk back to authority figures.

\section{Tensions and difficulties inherent in mathematical education for democracy}

Attempts to implement a mathematical education for democracy curriculum to promote democratic competence in mathematics students are not without obstacles, tensions, difficulties and contradictions.

\section{A tension between open and empowering materials}

It is difficult to design activities that are both open and empowering at the same time. For example, what do you do when a student is truly interested in an activity but it does not address any socially relevant problem? Similarly, because teachers want students to understand the functions and assumptions behind a real mathematical model, it is difficult for them to avoid proposing activities that are too structured and guided. Skovsmose (1990) sums up this problem:

Open material could result in open and democratic educational situations-but noempowerment is guaranteed; and empowering material could result in critical understanding - but no openness is guaranteed. (p. 120)

\section{A tension between democracy and authority}

Harris (1998) and Woodrow (1997) also note the everpresent dilemma of democracy and authority: for there to be democracy, some kind of authority is necessary; these elements are complementary. For example, to protect human rights, an authority must exist to defend and guarantee them. Vithal (1999) illustrates very clearly how this tension between democracy and authority may occur at different levels within the mathematics classroom: at the classroom level, within working groups, and even in the teacher-student, teacherresearcher domain. This tension brings two important points into focus: firstly, in order to promote democracy sometimes it is necessary to engage in non-democratic practices; and secondly, it is important to recognise that democracy requires some kind of authority, but it is also important to be aware that authority can turn into authoritarianism.

\section{The paradox of empowerment vs disempowerment}

Attempts to introduce mathematical activities into school curricula aimed at promoting democratic competencies in the students often face obstacles and resistance. For example, Almeida (2010) notes how such activities may cause delays in delivering the traditional curriculum. Such situations raise a paradox, as noted by Christiansen (2008), that the intention to empower students can be transformed into their actual disempowerment. For instance, we may propose activities that use mathematics to help the students to analyse social problems in their own communities. Behind this type of instruction is an assumption that these activities will empower students. However, whilst students may develop mathematical skills through such empowering activities, there is no guarantee that these skills will be those assessed on their exams. This could cause students to obtain poor marks or even to fail, ultimately disempowering them.

\section{The paradox of relevance vs indifference}

D'Ambrosio (2003) observes that it is unfortunate that many mathematics educators are not familiar with UNESCO's World Declaration on Education for All (UNESCO, 1990), which enshrined the right to education for all human beings. Due to the fact that human rights are an intimate part of democracy's legal dimensions, he notes that it is regrettable that there is not a widespread interest in the community of mathematics educators to know and try to implement the resolutions and mechanisms established in that document. The paradox is that, despite the vital importance of the UNESCO declaration, many mathematics educators are indifferent to this right, and to other dimensions of democracy. This paradox is similar to the issue raised by Ernest (2007) concerning the status of social justice within the mathematics education community:

Why do some individuals believe in social justice? There is great divergence in interest and commitment to social justice among mathematics educators. Some view it as central to their professional concerns, whereas others take no personal or professional interest in pursuing social justice issues. Why this divergence? (p. 3)

\section{The fundamental role of the teacher}

Two elements key to implementing mathematical education for democracy initiatives are the attitudes and skills of the teachers responsible. Consequently, the competencies 
that these teachers require to implement this educational approach in their classroom are the subject of much debate.

\section{Skills needed}

The specific skills that teachers need to possess can be divided into two groups: mathematical skills and pedagogical skills. With respect to the former, Christiansen (2008) holds that such teachers should be mathematically creative. This statement makes sense if they must select and even design empowering activities for their students. Christiansen also states that this requires that teachers understand the mathematical potential that such activities entail. They must understand why algorithms are applicable, must know the different ways a problem may be solved and must have a good understanding of how concepts and mathematical structures are interconnected.

D'Ambrosio (2003) also stresses the importance of being conscious of the dual role that mathematics plays in society. Mathematics can be used either as a tool to improve the welfare of humanity, or applied to increase inequality and injustice. Awareness of its dual role is especially important when teaching students to identify the uses and abuses of mathematical applications in society.

A mathematics classroom that aims to promote democratic values and attitudes should model deliberative interaction, argumentation, critical analysis of the information, and respect for the ideas of others. These features require that teachers possess the pedagogical skills to manage and promote such dynamics in the classroom. As Almeida (2010) points out, this requires that teachers use effective questioning techniques and appropriately manage class discussions. Christiansen (2008) argues that teachers should be aware of the pedagogical potential of activities both for the individual student and for the class as a whole. This requires, amongst other things, specific pedagogical knowledge about how students learn mathematics, and about concept development.

\section{Attitudes needed}

Besides having specific mathematical and pedagogical knowledge, teachers need to possess particular attitudes in order to promote democratic competencies in students. For instance, as Harris (1998) states, one of the important qualities that teachers must possess is commitment, particularly to social renewal along rational democratic lines. Harris, like D'Ambrosio (2003), identifies one of the major challenges of mathematics educators: to propose directions to counteract ingrained practices that exclude marginalised individuals and cultures on the periphery and deny them access to knowledge.

Christiansen (2008) stresses the importance of having critical teachers who are willing to speak up when they detect that a potentially empowering curriculum is being blocked or mathematical creativity is being hindered by limited assessment criteria representing traditional values or by recipe-like instructions about how to teach.

Another necessary attitude that Almeida (2010) highlights is the egalitarian treatment of students in the classroom. He claims that it is the responsibility of teachers to treat students as equal partners in the teaching-learning process. For example, students' misconceptions and mistakes should not be considered as failures of an intellectual inferior, but rather should be analysed to try to understand the students' reasoning processes and conceptions that led them to these results.

Along similar lines, Vithal (1999) suggests that teachers can be useful models of authority for students not only to learn about their individual limits, but also to learn that it is possible to raise their voice against authorities. But for this to happen, teachers must be willing to give up part of the authority they traditionally have enjoyed in the classroom and understand that challenges to their authority are part of what constitutes a democratic education for their students.

Finally, another of the necessary attitudes that some texts address is a willingness of teachers to work in academic environments that are full of uncertainty. This is because, as Skovsmose (1990) observes, the evolution of a lesson based on open activities may be unpredictable, so the control that teachers usually have over the mathematical knowledge that is assigned and discussed in the classroom can be diluted and replaced with uncertainty.

\section{Rights and obligations}

Obligations, as conceptualised by Christiansen (2008), are those qualities that teachers responsible for implementing a mathematical education for democracy should possess. Framed in a juridical sort of rights and obligations discourse that is one dimension of democracy, Christiansen also refers to the rights of teachers:

In extension of these obligations, it must also be a democratic right for teachers to have a say in how curricula, guidelines and recommended teaching materials are put together; a right to have the many years of experience from the teaching profession being put to use. A right to be taken serious if they choose to criticise curricula and required teaching methods for being too idealistic and too demanding to realise in practice. Do we secure these rights? (pp. 81-82)

We think that this conceptualisation is very important as it highlights not only the qualities that the teachers should possess, but also the rights that they should enjoy.

\section{Selected criticisms}

\section{More empirical research is needed}

Mathematics education for democracy has drawn its share of criticisms. Some of these criticisms are aimed at applications of this approach, whilst others refer to unwanted results that it could produce. We reviewed enough works for it to be evident to us that most of this literature consists of 
programmatic theoretical and rhetorical statements rather than careful empirical research. There is a clear need for empirical studies to test and expand these theoretical ideas. Vithal (1999) explicitly addresses this issue:

There is now a considerable literature exploring the connections between mathematics education and democratic society, much of it theoretical about what could or should occur. The question is what happens when an attempt is made to deliberately realise such a link in a mathematics classroom. (p. 27)

\section{Possible discriminatory outcomes}

One of the paradoxes of empowerment vs disempowerment is that mathematics education for democracy may lead to results that are contrary to expectations. Woodrow (1997) points to some studies that show that this approach may produce discriminatory results. For example, he cites a study where some pre-service teachers were empowered to create new curricula based on exploratory and investigative work. However, when faced with the school reality and having found out that school mathematics can be quite ritualistic and confirmatory, one of these empowered teachers became so disillusioned that he left teaching.

\section{An imposition of emancipation}

Mathematics education for democracy consists of a series of mathematical activities and modes of interaction that are considered to be beneficial and empowering. They are based on the assumption that teachers with the appropriate training can tell what kinds of education will further the civic development of students. Yet entailed in this proposition is the assumption that their superior position gives them the right to modify the curriculum, and to decide what is beneficial for their students. Christiansen (2008) questions this 'right':

Who has, when it comes down to it, the right to influence the purpose and content of education? Does our insistence on these 'critical examples' end up being 'imposition of emancipation'? How would the historically advantaged feel if the educational system really came to function on the premises of the historically disadvantaged? If our cultural capital ... was depreciated overnight? Would we not object to the purpose and content forced upon us - even if claimed to be emancipatory? (p. 76)

Christiansen's criticism is similar to Ernest's (2010) critique of Critical Theory, namely that its judgements also require an epistemologically and ethically privileged standpoint.

\section{The applicability and relevance of a critical ideology}

Valero (1999) makes a criticism of the critical ideology that underlies the link between mathematics education and democracy that seems particularly relevant to us as Latin Americans. We refer to the theoretical position that holds that mathematics is ubiquitous in modern societies, and that mathematical models and applications influence many of the decisions that affect and shape modern societies. Valero (1999) analyses this ideology from a Latin American perspective:
Critical ideology overemphasizes the role of mathematics in society. In Latin America, the power structure has lead to a clientelist political system where decisions are made based on personal loyalty of clients to patrons, political convenience, power of conviction through the use of language or violent and physical imposition. In this 'rationality', mathematics does not necessarily constitute a formatting power that greatly influences decision-making. (p. 22)

Harris (1998) makes a similar criticism that is also relevant in the Latin American context:

There is a peculiar pointlessness in advocating schooling for democracy and authority within broader social contexts where schooling itself undemocratically favours some individuals and groups and disadvantages others, or where the potential for individual autonomous development is otherwise fundamentally stifled. Under those circumstances 'schooling for democracy' and 'education for autonomy' are either slogans, fashionable ideals or hypocritical rhetoric. (p. 176)

\section{Discussion}

This literature review was motivated and driven by our own curiosity and personal interests. We live in Mexico, a country with a developing but still fragile democracy. When we discovered that there was a research area focused on studying the relationship between mathematics education and democracy, we were very interested in studying it. We wanted to know what the links between mathematics education and democracy are, but we also wanted to know what knowledge and strategies our field has produced that may be used to promote democracy.

\section{What are the main ideas that we found in the literature?}

The first key idea that we found in the literature is that indeed there are connections between mathematics education and democracy, connections that we have already presented. However, these connections are not always positive. Mathematics education can promote democratic competences and values, but it can also inhibit them, and create social inequalities.

The second key idea we encountered is that there is a generalised interest in the research community to promote equality, democratic values and democratic competencies in mathematics students and teachers. This is a task that is far from trivial. The relationship between mathematics education and democracy is a relationship fraught with tension, and theoretical and practical difficulties.

The third idea that became clear to us is that the majority of research on mathematics education and democracy has been developed at a theoretical level. More empirical research is necessary in order to test and expand these theoretical ideas. As noted by Vithal (2000, p. 1), 'hard evidence to support (or refute) theoretical propositions about empowerment, emancipation, democracy, social justice, equity and so on through mathematics education are still rather thin.' 


\section{Some topics that need to be researched}

There are a number of research topics, theoretical and empirical, pertinent to the further development of mathematics education for democracy that are absent, are emerging, or have been little explored in the literature. The three links between mathematics education and democracy that we have identified may help to put these theoretical and practical research topics into perspective, within the limitations of this literature review.

\section{Longitudinal studies}

As we have seen, several didactical proposals to promote critical mathematical skills in students have been made. Some of these proposals that call for the use of real mathematical models in the teaching of mathematics have been tested in actual mathematics classrooms. However, our review found no examples of longitudinal studies that show the long-term effects of this type of instruction. There is some evidence that the students who experience this type of instruction discuss and reflect on the implications and consequences of the application of such mathematical models. But how long do such reflections and attitudes last for these students? Is it true that those students who receive this type of mathematical instruction will develop into critical citizens? Unfortunately, this type of empirical research is absent in the literature reviewed.

\section{Teacher education}

In order to implement a mathematical education for democracy, special teachers are needed. Such teachers should be capable of providing their students with opportunities to develop critical mathematical skills and democratic attitudes. However, very few studies address how to structure and implement a teacher education to produce teachers of this kind. Although we are aware of the existence of empirical and theoretical studies in the field of mathematics teacher education that seek to promote a more socially just mathematical education (see e.g. the double special issue on social justice published in the Journal of Mathematics Teacher Education, Volume 12, numbers 3 and 6, 2009), we think that because of the fundamental role played by the teacher, this is an area that still needs to be developed further.

\section{Textbook development}

One issue that is closely related to the implementation of a mathematical education for democracy is the production of textbooks. Textbooks are important tools that help to organise and structure mathematics lessons. It is necessary to produce textbooks that will foster critical mathematical skills in students. Such books may contain, amongst other things, regional examples of applications of mathematics in the analysis and solution of social problems, or even examples of the use of mathematics amongst political actors and governance systems.

\section{The concept of power vs the concept of democracy}

During the construction process of this literature review, we found some articles addressing the concept of power and its connections with the concept of democracy. In particular we refer to the articles by Ernest (2002) and Valero (2007). There we discovered two theoretical issues that we think deserve to be discussed in more depth in our community.

Firstly we learned that power is a concept underlying the discussion about mathematics education and democracy, especially when we refer to Link 1 mentioned in this review, where it is assumed that students are empowered through the acquisition of certain mathematical skills. Valero (2007) discusses and explains how this conception of empowerment, which presupposes power transference, is problematic and leads to contradictions.

On the other hand, when we read the concept of epistemological empowerment as presented in Ernest (2002) we found some similarities with the concept of democratic competence. This is because to achieve epistemological empowerment it is necessary not only to gain mastery over some mathematical knowledge, but also to possess certain values and attitudes such as personal engagement with mathematics and confidence. As Ernest (2002) put it:

Only when all of these powers are developed will they [the students] feel they are entitled to be confident in applying mathematical reasoning, judging the correctness of such applications themselves, and critically appreciating (including rejecting, in some cases) the applications and uses of mathematics by others, across all types of contexts, in school and society. (p. 11)

Our point here is that it is necessary to further discuss if and how the theoretical concepts related to power complement or contradict the concepts that have been used in the discussion of mathematics education and democracy. Perhaps concepts such as empowerment and democratic competence need to be revisited and even reformulated.

\section{How values and attitudes are constituted}

Bishop (2002) affirms that values are an issue that underlie any discussion of social justice and democratisation. Through our literature review we noted that the empirical research investigating how values and attitudes are constituted is virtually non-existent. There are questions related to the values and attitudes required for the constitution of democratic competence that need to be addressed. For example, where do values and attitudes come from and how are they constituted? Do they come from the textbooks? Are they generated through interpersonal relationships in the classroom? Does the mathematics teacher transmit them? This is certainly a research topic that needs to be explored. However, the study of this topic may be theoretically complex since there are different conceptualisations of values and attitudes in mathematics education.

\section{Curriculum studies}

There are authors like Bopape (1998) who mention that in the past the curriculum has perpetuated race, class gender and ethnic division. However, during our review we found only 
one empirical study showing how a mathematics curriculum can serve as a tool for sorting citizens. We refer to the work of Rogers (1998), which is a study that shows how different types of mathematics were taught to different groups of people in England during the Industrial Revolution. We believe it is necessary to carry out more contemporary studies, such as the one developed by Ho (2012), that demonstrate how the mathematics curriculum can serve as a stratification tool in modern societies.

\section{A final comment}

We would like to finish this article by pointing out the need to disseminate more widely, and mainly in Latin American countries, the research related to mathematics education and democracy. The Latin American region is a geographical area constituted by several countries with developing democracies. This is why we consider it relevant that the ideas we have learned through this literature review be disseminated more broadly in these countries. We have the impression that, with few exceptions, this perspective of mathematics education is not widely known in the region. We hope that in future we can help to disseminate these ideas.

\section{Acknowledgements}

We would like to thank James B. Greenberg for proofreading the final version of the manuscript.

\section{Authors' contributions}

M.S.A. (National Polytechnic Institute) was the project leader. M.S.A. and J.G.M.Z. (National Polytechnic Institute) located, analysed and synthesised the relevant literature. M.S.A. wrote the manuscript, taking into consideration J.G.M.Z's suggestions.

\section{References}

Almeida, D. (2010). Are there viable connections between mathematics, mathematical proof and democracy? Philosophy of Mathematics Education Journal, 25. Available
from http://people.exeter.ac.uk/PErnest/pome25/D.\%20F.\%20Almeida\%20\%20 from http://people.exeter.ac.uk/PErnest/pom

Amit, M., \& Fried, M.N. (2002). High-stakes assessment as a tool for promoting mathematical literacy and the democratization of mathematics education. The
Journal of Mathematical Behavior, 21(4), 499-514. http://dx.doi.org/10.1016/ Journal of Mathematical
S0732-3123(02)00147-5

Anderson, C.R., \& Tate, W.F. (2008). Still separate, still unequal: Democratic access to mathematics in U.S. schools. In L.D. English (Ed.), Handbook of internationa research in mathematics education (2nd edn., pp. 299-318). New York, NY Routledge. PMCid:3122979

Bishop, A.J. (2002). Research, policy and practice: The case of values. In P. Valero, \& $\mathrm{O}$. Skovsmose (Eds.), Proceedings of the Third Mathematics Education and Society Conference (pp. 1-7). Copenhagen: Centre for Research in Learning Mathematics. Available from http://mes3.learning.aau.dk/Papers/Bishop.pdf

Bopape, M. (1998). The South African new mathematics curriculum: People's mathematics for people's power? In P. Gates, \& T. Cotton (Eds.), Proceedings of the First Mathematics Education and Society Conference. Nottingham: The Centre for the Study of Mathematics Education, Nottingham University. Available from http://www.nottingham.ac.uk/csme/meas/papers/bopape.html

Christiansen, I.M. (2006). Mathematical Literacy as a school subject: Failing the progressive vision? Pythagoras, 64, 6-13. http://dx.doi.org/10.4102/pythagoras. v0i64.94

Christiansen, I.M. (2008). Some tensions in mathematics education for democracy In B. Sriraman (Ed.), International perspectives on social justice in mathematics education (pp. 69-86). Missoula, MT: Information Age Publishing. PMid:18290894

D'Ambrosio, U. (1990). The role of mathematics education in building a democratic and just society. For the Learning of Mathematics, 10(3), 20-23. Available from http://www.jstor.org/stable/40247989
D'Ambrosio, U. (2003). The role of mathematics in building a democratic society. In B.L. Madison, \& L.A. Steen (Eds.), Quantitative literacy. Why numeracy matters for schools and colleges (pp. 235-238). Princeton, NJ: The National Council on for schools and colleges (pp. 235-238). Princeton, NJ: The National Council on
Education and the Disciplines and The Woodrow Wilson National Fellowship Education and the Disciplines and The Woodrow Wilson Nation.
Foundation. Available from http://www.maa.org/ql/qltoc.html

De Mattos, A.C., \& Batarce, M.S. (2010). Mathematics education and democracy. ZDM: The International Journal on Mathematics Education, 42(3/4), 281-289. http://dx.doi.org/10.1007/s11858-009-0232-2

Ernest, P. (2002). What is empowerment in mathematics education? In P. Valero, $\&$ O. Skovsmose (Eds.), Proceedings of the Third Mathematics Education and Society Conference (pp. 1-12). Copenhagen: Centre for Research in Learning Mathematics. Available from http://mes3.learning.aau.dk/Papers/Ernest.pdf

Ernest, P. (2007). Why social justice? Philosophy of Mathematics Education Journal, 21. Available from http://people.exeter.ac.uk/PErnest/pome21/Ernest\%20\%20 Why\%20Social\%20Justice.doc

Ernest, P. (2010). The scope and limits of critical mathematics education. Philosophy of Mathematics Education Journal, 25. Available from http://people.exeter.ac.uk/ PErnest/pome25/Paul\%20Ernest\%20\%20The\%20Scope\%20and\%20Limits\%20 of $\% 20$ Critical\%20Mathematics\%20Education.doc

Gutiérrez, R. (2010). Editorial: The sociopolitical turn in mathematics education. Journal for Research in Mathematics Education, 41(0), 4-32. Available from http://www.nctm.org/uploadedFiles/Journals_and_Books/JRME/articles/JRME Special_Equity_Issue/jrme2010-08-5a.pdf

Hanna, G., \& Sidoli, N. (2002). The story of ESM. Educational Studies in Mathematics, 50(2), 123-156. http://dx.doi.org/10.1023/A:1021162617070

Hannaford, C. (1998). Mathematics teaching is democratic education. ZDM: The International Journal on Mathematics Education, 30(6), 181-187. http://dx.doi. $\mathrm{org} / 10.1007 / \mathrm{s} 11858-998-0008-0$

Harris, K. (1998). Mathematics teachers as democratic agents. ZDM: The Internationa Journal on Mathematics Education, 30(6), 174-180. http://dx.doi.org/10.1007/ s11858-998-0007-1

Ho, L-C. (2012). Sorting citizens: Differentiated citizenship education in Singapore. Journal of Curriculum Studies, 44(3), 403-428. http://dx.doi.org/10.1080/00220 Journal of Curricul
272.2012.675359

Johansen, L. (2002). Why teach math to the "excluded"? In P. Valero, \& O. Skovsmose (Eds.), Proceedings of the Third Mathematics Education and Society Conference (pp. 1-12). Copenhagen: Centre for Research in Learning Mathematics. Available from http://mes3.learning.aau.dk/Papers/Johansen.pdf

Knijnik, G. (2002). Two political facets of Mathematics Education in the production of social exclusion. In P. Valero, \& O. Skovsmose (Eds.), Proceedings of the Third Mathematics Education and Society Conference (pp. 1-9). Copenhagen: Centre for Research in Learning Mathematics. Available from http://mes3.learning.aau. $\mathrm{dk} /$ Papers/Knijnik.pdf

Malloy, C.E. (2008). Looking throughout the world for democratic access to mathematics. In L.D. English (Ed.), Handbook of international research in mathematics education (2nd edn., pp. 20-31). New York, NY: Routledge.

Moreira, L. (2000). Some reflections on democracy with regard to curricula and vice versa. In J.P. Matos, \& M. Santos (Eds.), Proceedings of the Second Mathematics Education and Society Conference. Lisbon: Universidade de Lisboa. Available from http://nonio.fc.ul.pt/mes2/moreira.doc

Murillo, G., \& Valero, P. (1996). De una democracia restringida hacia una participativa: El peligro de la contra-reforma y la regresión en Colombia. In E. Diniz (Ed.), O Desafio da Democracia na América Latina (pp. 493-511). Rio de Janeiro: IUPERJ.

Orrill, R. (2001). Mathematics, numeracy, and democracy. In L.A. Steen (Ed.) Mathematics and Democracy. The case for quantitative literacy (pp. 8-20). Princeton, NJ. The National Council on Education and the Disciplines and The Woodrow Wilson National Fellowship Foundation. Available from http://www. Woodrow Wilson National Fellowship
maa.org/ql/mathanddemocracy.html

Pais, A., \& Valero, P. (2012). Researching research: Mathematics education in the political. Educational Studies in Mathematics, 80(1/2), 9-24. http://dx.doi. org/10.1007/s10649-012-9399-5

Rogers, L. (1998). Society, mathematics and the cultural divide: ideologies of policy and practice 1750-1900. In P. Gates, \& T. Cotton (Eds.), Proceedings of the First Mathematics Education and Society Conference. Nottingham: The Centre for the Study of Mathematics Education, Nottingham University. Available from http:// www.nottingham.ac.uk/csme/meas/papers/rogers.htm

Skovsmose, O. (1990). Mathematical education and democracy. Educational Studies in Mathematics, 21(2), 109-128. http://dx.doi.org/10.1007/BF00304897

Skovsmose, O. (1994). Towards a philosophy of critical mathematics education Dordrecht: Kluwer Academic Publishers.

Skovsmose, O. (1998). Linking mathematics education and democracy: Citizenship, mathematical archaeology, mathemacy and deliberative interaction. ZDM: The International Journal on Mathematics Education, 30(6), 195-203. http://dx.doi. org/10.1007/s11858-998-0010-6

Skovsmose, O., \& Valero, P. (2001). Breaking political neutrality: The critical engagement of mathematics education with democracy. In B. Atweh, H. Forgasz, \& B. Nebres (Eds.), Sociocultural research on mathematics education: An international perspective (pp. 37-55). Mahwah, NJ: Lawrence Erlbaum.

Skovsmose, O., \& Valero, P. (2008). Democratic access to powerful mathematica ideas. In L.D. English (Ed.), Handbook of international research in mathematics education (2nd edn., pp. 415-438). New York, NY: Routledge. 
Thomas, J. (2010). Policyissues in the teaching and learning of the mathematical sciences at university level. International Journal of Mathematical Education in Science and Technology, 31(1), 133-142. http://dx.doi.org/10.1080/002073900287453

UNESCO. (1990). The world declaration on education for all and framework for action to meet basic learning needs. New York, NY: UNESCO. Available from www. unesco.org/education/pdf/JOMTIE_E.PDF

Valero, P. (1999). Deliberative mathematics education for social democratization in Latin America. ZDM: The International Journal on Mathematics Education, 31(1), 20-26. http://dx.doi.org/10.1007/s11858-999-0004-z

Valero, P. (2007). What has power got to do with mathematics education? Philosophy of Mathematics Education Journal, 21. Available from http://people.exeter.ac.uk/ PErnest/pome21/Valero\%20\%20What\%20has\%20Power\%20Got\%20to\%20 Do\%20with\%20Math\%20Ed.doc
Vithal, R. (1999). Democracy and authority: A complementarity in mathematics education? ZDM: The International Journal on Mathematics Education, 31(1), 27-36. http://dx.doi.org/10.1007/s11858-999-0005-y

Vithal, R. (2000). Re-searching mathematics education from a critical perspective. In J.P. Matos, \& M. Santos (Eds.), Proceedings of the Second Mathematics Education and Society Conference (pp. 1-22). Lisbon: Universidade de Lisboa. Available from and Society Conference (pp. 1-22). Lisb
$\mathrm{http}: / /$ nonio.fc.ul.pt/mes2/renuka.pdf

Wagner, D., \& Davis, B. (2010). Feeling number: grounding number sense in a sense of quantity. Educational Studies in Mathematics, 74(1), 39-51. http://dx.doi. org/10.1007/s10649-009-9226-9

Woodrow, D. (1997). Democratic education: Does it exist-especially for mathematics education? For the Learning of Mathematics, 17(3), 11-16. Available from http:// www.jstor.org/stable/40248247 
APPENDIX 1

\section{Bibliographic details of the references consulted for the development of the literature review}

\section{Layer 1 - Journals}

\section{Africa}

Christiansen, I.M. (2006). Mathematical literacy as a school subject: Failing the progressive vision? Pythagoras, 64, 6-13. http://dx.doi.org/10.4102/pythagoras. v0i64.94

\section{Australasia}

Goos, M., Dole, S., \& Geiger, V. (2011). Improving numeracy education in rural schools: A professional development approach. Mathematics Education Research Journal, 23(2), 129-148. http://dx.doi.org/10.1007/s13394-011-0008-1

Walshaw, M. (2007). Research as a catalyst for the promotion of equity. Mathematics Education Research Journal, 19(3), 1-2. http://dx.doi.org/10.1007/BF03217458

\section{Europe}

Almeida, D. (2010). Are there viable connections between mathematics, mathematical proof and democracy? Philosophy of Mathematics Education Journal, 25. Available from http://people.exeter.ac.uk/PErnest/pome25/D.\%20F.\%20Almeida\%20\%20 Are\%20There\%20Viable\%20Connections.docx

Boylan, M. (2007). Teacher questioning in communities of political practice. Philosophy of Mathematics Education Journal, 20. Available from http://people.exeter.ac.uk/ PErnest/pome20/Boylan\%20Teacher\%20Questioning\%20in\%20Communities.doc

Dowling, P. (2007). Organising the social. Philosophy of Mathematics Education Journal, 21. Available from http://people.exeter.ac.uk/PErnest/pome21/ Dowling\%200rganising\%20the\%20Social.doc

Frankenstein, M. (2010). Critical mathematics education: An application of Paulo Freire's epistemology. Philosophy of Mathematics Education Journal, 25. Available from http://people.exeter.ac.uk/PErnest/pome25/Marilyn\%20Frankenstein\%20 $\% 20$ Critical\%20Mathematics\%20Education.doc

Nikolakaki, M. (2010). Investigating critical routes: The politics of mathematics education and citizenship in capitalism. Philosophy of Mathematics Education Journal, 25. Available from http://people.exeter.ac.uk/PErnest/pome25/ Maria\%20Nikolakaki\%20\%20Investigating\%20Critical\%20Routes.doc

Valero, P. (2007). What has power got to do with mathematics education? Philosophy of Mathematics Education Journal, 21. Available from http://people.exeter.ac.uk/ PErnest/pome21/Valero\%20\%20What\%20has\%20Power\%20Got\%20to\%20 Do\%20with\%20Math\%20Ed.doc

Walls, F. (2007). Using rights-based frameworks for rethinking teacher-directed pedagogies of mathematics. Philosophy of Mathematics Education Journal, 20. Available from http://people.exeter.ac.uk/PErnest/pome20/Walls\%20\%20 Using\%20right-based\%20frameworks\%20.doc

\section{International}

Bishop, A. J. (1999). Mathematics teaching and values education - an intersection in need of research. ZDM: The International Journal on Mathematics Education 31(1), 1-4. http://dx.doi.org/10.1007/s11858-999-0001-2

D'Ambrosio, U. (1990). The role of mathematics education in building a democratic and just society. For the Learning of Mathematics, 10(3), 20-23. Available from http://www.jstor.org/stable/40247989

De Mattos, A.C., \& Batarce, M.S. (2010). Mathematics education and democracy. ZDM: The International Journal on Mathematics Education, 42(3/4), 281-289. http://dx.doi.org/10.1007/s11858-009-0232-2

Greer, B. (2009). Estimating Iraqi deaths: A case study with implications for mathematics education. ZDM: The International Journal on Mathematics Education, 41(1/2), 105-116. http://dx.doi.org/10.1007/s11858-008-0147-3

Hannaford, C. (1998). Mathematics teaching is democratic education. ZDM: The International Journal on Mathematics Education, 30(6), 181-187. http://dx.doi. org/10.1007/s11858-998-0008-0

Harris, K. (1998). Mathematics teachers as democratic agents. ZDM: The International Journal on Mathematics Education, 30(6), 174-180. http://dx.doi.org/10.1007/ s11858-998-0007-1

Lengnik, K. (2005). Reflecting mathematics: An approach to achieve mathematical literacy. ZDM: The International Journal on Mathematics Education, 37(3), 246-249. http://dx.doi.org/10.1007/s11858-005-0016-2

O'Donoghue, J. (1995). Numeracy and further education: beyond the millennium. International Journal of Mathematical Education in Science and Technology, 26(3), 389-405. http://dx.doi.org/10.1080/0020739950260308

Skovsmose, O. (1985). Mathematical education versus critical education. Educationa Studies in Mathematics, 16(4), 337-354. http://dx.doi.org/10.1007/BF00417191
Skovsmose, O. (1988). Mathematics as part of technology. Educational Studies in Mathematics, 19(1), 23-41. http://dx.doi.org/10.1007/BF00428383

Skovsmose, O. (1990). Mathematical education and democracy. Educational Studies in Mathematics, 21(2), 109-128. http://dx.doi.org/10.1007/BF00304897

Skovsmose, O. (1992). Democratic competence and reflective knowing in mathematics. For the Learning of Mathematics, 12(2), 2-11. Available from http://www.jstor. org/stable/40248044

Skovsmose, O. (1994). Towards a critical mathematics education. Educational Studies in Mathematics, 27(1), 35-57. http://dx.doi.org/10.1007/BF01284527

Skovsmose, O. (1998). Linking mathematics education and democracy: Citizenship, mathematical archaeology, mathemacy and deliberative interaction. ZDM: The International Journal on Mathematics Education, 30(6), 195-203. http://dx.doi. org/10.1007/s11858-998-0010-6

Skovsmose, O. (2001). Landscapes of investigation. ZDM: The International Journal on Mathematics Education, 33(4), 123-132. http://dx.doi.org/10.1007/BF02652747

Skovsmose, O. (2007). Doubtful rationality. ZDM: The International Journal on Mathematics Education, 39(3), 215-224. http://dx.doi.org/10.1007/s11858-0070024-5

Spielman, L.J. (2008). Equity in mathematics education: unions and intersections of feminist and social justice literature. ZDM: The International Journal on Mathematics Education, 40(4), 647-657. http://dx.doi.org/10.1007/s11858-0080113-0

Thomas, J. (2000). Policy issues in the teaching and learning of the mathematical sciences at university level. International Journal of Mathematical Education in Science and Technology, 31(1), 133-142. http://dx.doi.org/10.1080/002073900287453

Tutak, F.A., Bondy, E., \& Adams, T.L. (2011). Critical pedagogy for critical mathematics education. International Journal of Mathematical Education in Science an Technology, 42(1), 65-74. http://dx.doi.org/10.1080/0020739X.2010.510221

Valero, P. (1999). Deliberative mathematics education for social democratization in Latin America. ZDM: The International Journal on Mathematics Education, 31(1), 20-26. http://dx.doi.org/10.1007/s11858-999-0004-z

Valero, P. (2007). A socio-political look at equity in the school organization of mathematics education. ZDM: The International Journal on Mathematics Education, 39(3), 225-233. http://dx.doi.org/10.1007/s11858-007-0027-2

Vithal, R. (1999). Democracy and authority: A complementarity in mathematics education? ZDM: The International Journal on Mathematics Education, 31(1) 27-36. http://dx.doi.org/10.1007/s11858-999-0005-y

Vithal, R., \& Skovsmose, O. (1997). The end of innocence: A critique of 'ethnomathematics'. Educational Studies in Mathematics, 34(2), 131-157. http:// dx.doi.org/10.1023/A:1002971922833

Wagner, D., \& Davis, B. (2010). Feeling number: grounding number sense in a sense of quantity. Educational Studies in Mathematics, 74(1), 39-51. http://dx.dol. org/10.1007/s10649-009-9226-9

Woodrow, D. (1997). Democratic education: Does it exist - especially for mathematics education? For the Learning of Mathematics, 17(3), 11-16. Available from http:// www.jstor.org/stable/40248247

\section{Latin America}

Bernardi, L.S., \& Caldeira, A.D. (2012). Educação matemática na escola indígena sob uma abordagem crítica. [Mathematics education in an indigenous schools undera critical approach]. Bolema: Boletim de Educação Matemática, 26(42B), 409-431. Available from http://www.periodicos.rc.biblioteca.unesp.br/index.php/bolema/ article/view/5765

Campos, C.R., Jacobini, O.R., Wodewotzki, M.L.L., \& Ferreira, D.H.L. (2011). Educação estatística no contexto da educação crítica. [Statistics education in the context of estation in the context of Available from http://www.periodicos.rc.biblioteca.unesp.br/index.php/bolema/ Available from htte:
article/view/5104

Jacobini, O.R., \& Wodewotzki, M.L. (2006). Uma reflexão sobre a modelagem matemática no contexto da educação matemática crítica. [A reflection on mathematical modeling in the context of critical mathematics education] Bolema: Boletim de Educação Matemática, 19(25), 1-16. Available from http:// www.periodicos.rc.biblioteca.unesp.br/index.php/bolema/article/view/1876

Pinheiro, N.M., \& Bazzo, W.A. (2009). Caso simulado no ensino-aprendizagem de matemática: Ensinar sob uma abordagem crítica. [Simulated case in the teaching-learning of mathematics: Teaching under a critical approach]. Boletim de Educação Matemática, 22(32), 101-122. Available from http://www.periodicos. rc.biblioteca.unesp.br/index.php/bolema/article/view/2074

\section{North America}

Amit, M., \& Fried, M.N. (2002). High-stakes assessment as a tool for promoting mathematical literacy and the democratization of mathematics education. The Journal of Mathematical Behavior, 21(4), 499-514. http://dx.doi.org/10.1016/ S0732-3123(02)00147-5

Gutiérrez, R. (2010). The sociopolitical turn in mathematics education. Journal for Research in Mathematics Education, 41(0) 4-32. Available from http://www. Research in Mathematics Education, 41(0), 4-32. Available from http://www.
nctm.org/uploadedFiles/Journals_and_Books/JRME/articles/JRME_Special Equity_Issue/jrme2010-08-5a.pdf

Parks, A.N., \& Schmeichel, M. (2012). Obstacles to addressing race and ethnicity in the mathematics education literature. Journal for Research in Mathematics Education, 43(3), 238-252. Available from http://www.jstor.org/stable/10.5951/ jresematheduc.43.3.0238

Skovsmose, O. (2006). Research, practice, uncertainty and responsibility. The Journa of Mathematical Behavior, 25(4), 267-284. http://dx.doi.org/10.1016/j.jmathb. 2006.11.002 


\section{Layer 2 - Conference proceedings}

\section{ICME 11}

Gellert, U., \& Jablonka, E. (2008, July). The demathematising effect of technology: Calling for critical competence. Discussion Group 3: Mathematics education: Calling for critical competence. Discussion Group 3: Mathematics education: Mathematical Education, Monterrey, Mexico. Available from http://dg.icme11. org/document/get/63

\section{ICME 10}

Skovsmose, O. (2004). Critical mathematics education for the future. In M. Niss (Ed.) Proceedings of the Tenth International Congress on Mathematical Education (pp. Proceedings of the Tenth International Congress on Mathematical Education (pp.
1-19). Roskilde, Denmark: IMFUFA, Roskilde University. Available from http:// vbn.aau.dk/files/17034122/CriticalMathematicsEducation

\section{CERME 7}

Andersson, A., \& Norén, E. (2011). Agency in mathematics education. In M. Pytlak, T. Rowland, \& E. Swoboda (Eds.), Proceedings of the Seventh Congress of the . . Rowland, \& European Society for Research in Mathematics Education (pp. 1389-1398). rzeszow.pl/WG/10/CERME7_WG10_AnderssonNoren.pdf

\section{CERME 6}

Valero, P. (2009). Mathematics education as a network of social practices. In V. Durand-Guerrier, S. Soury-Lavergne, \& F. Arzarello (Eds.), Proceedings of the Sixth Durand-Guerrier, S. Soury-Lavergne, \& F. Arzarello (Eds.), Proceedings of the Sixth LV-LXXX). Lyon, France: Institut National De Recherche Pédagogique. Available from http://ife.ens-lyon.fr/publications/edition-electronique/cerme6/plenary2from http://if
valero.pdf

\section{MES 1}

Bopape, M. (1998). The South African new mathematics curriculum: People's mathematics for people's power? In P. Gates, \& T. Cotton (Eds.), Proceedings of the First Mathematics Education and Society Conference. Nottingham: The Centre for the Study of Mathematics Education, Nottingham University. Available from http://www.nottingham.ac.uk/csme/meas/papers/bopape.html

Moreira, L., \& Carreira, S. (1998). No excuses to command, no excuses to obey, no excuses to ignore. Some data to reflect upon. In P. Gates, \& T. Cotton (Eds.), Proceedings of the First Mathematics Education and Society Conference. Nottingham: The Centre for the Study of Mathematics Education, Nottingham University. Available from http://www.nottingham.ac.uk/csme/meas/papers/ moreiracarreira.htm

Skovsmose, O. (1998). Aporism, and the problem of democracy in mathematics education. In P. Gates, \& T. Cotton (Eds.), Proceedings of the First Mathematics Education and Society Conference. Nottingham: The Centre for the Study of Mathematics Education, Nottingham University. Available from http://www. nottingham.ac.uk/csme/meas/plenaries/skovsmose.html

\section{MES 2}

Moreira, L. (2000). Some reflections on democracy with regard to curricula and vice versa. In J.P. Matos, \& M. Santos (Eds.), Proceedings of the Second Mathematics Education and Society Conference. Lisbon: Universidade de Lisboa. Available from http://nonio.fc.ul.pt/mes2/moreira.doc

Vithal, R. (2000). Re-searching mathematics education from a critical perspective. In J.P. Matos, \& M. Santos (Eds.), Proceedings of the Second Mathematics Education and Society Conference. Lisbon: Universidade de Lisboa. Available from http:// nonio.fc.ul.pt/mes2/renuka.pdf

\section{MES 3}

Bishop, A.J. (2002). Research, policy and practice: The case of values. In P. Valero, \& O. Skovsmose (Eds.), Proceedings of the Third Mathematics Education and Society Conference. Copenhagen: Centre for Research in Learning Mathematics. Available from http://mes3.learning.aau.dk/Papers/Bishop.pdf

Carvalho, V., Mendonça, M.C.D., Santos, S.A., \& Santos-Wagner, V.M. (2002) In P. Valero, \& O. Skovsmose (Eds.), Proceedings of the Third Mathematic Education and Society Conference. Copenhagen: Centre for Research in Learning Mathematics. Available from http://mes3.learning.aau.dk/Papers/Carvalho.pdf
Ernest, P. (2002). What is empowerment in mathematics education? In P. Valero, \& O. Skovsmose (Eds.), Proceedings of the Third Mathematics Education and Society Conference. Copenhagen: Centre for Research in Learning Mathematics. Available from http://mes3.learning.aau.dk/Papers/Ernest.pdf

Johansen, L. Ф. (2002). Why teach math to the "excluded"? In P. Valero, \& O. Skovsmose (Eds.), Proceedings of the Third Mathematics Education and Society Conference. Copenhagen: Centre for Research in Learning Mathematics. Available from http:// mes3.learning.aau.dk/Papers/Johansen.pdf

Knijnik, G. (2002). Two political facets of mathematics education in the production of social exclusion. In P. Valero, \& O. Skovsmose (Eds.), Proceedings of the Third Mathematics Education and Society Conference. Copenhagen: Centre for Research in Learning Mathematics. Available from http://mes3.learning.aau.dk/ Papers/Knijnik.pdf

Popkewitz, T. (2002). Whose heaven and whose redemption? The alchemy of the mathematics curriculum to save (please check one or all of the following) (a) the mathematics curriculum to save (please check one or all of the following) (a) the (e) the individual. In P. Valero, \& O. Skovsmose (Eds.), Proceedings of the Third Mathematics Education and Society Conference, Addendum. Copenhagen: Centre Mathematics Education and Society Conference, Addendum. Copenhagen: Centre dk/Plenaries/Popkewitz.pdf

\section{MES 5}

Chartres, M. (2008). Are my students engaged with critical mathematics education? In J.F. Matos, P. Valero, \& K. Yasukawa (Eds.), Proceedings of the Fifth Mathematics Education and Society Conference (pp. 186-196). Lisbon: Centro de Investigação Education and Society Conference (pp. 186-196). Lisbon: Centro de Investigação em Educação, Universidade de Lisboa - Department of Education, Learning files/2376308/Proceedings_MES5.pdf

\section{MES 6}

Martin, D.B. (2010). Not-so-strange bedfellows: Racial projects and the mathematics education enterprise. In U. Gellert, E. Jablonka, \& C. Morgan (Eds.), Proceedings of the Sixth Mathematics Education and Society Conference, Vol. 1 (pp. 57-79) Berlin: Freie Universität Berlin. Available from http://www.ewi-psy.fu-berlin.de/ en/v/mes6/documents/proceedings/Band_1_Finale.pdf

Sinclair, N., \& Pimm, D. (2010). Mathematics, democracy and the aesthetic. In U. Gellert, E. Jablonka, \& C. Morgan (Eds.), Proceedings of the Sixth Mathematics Education and Society Conference, Vol. 2 (pp. 57-79). Berlin: Freie Universität Berlin. Available from http://www.ewi-psy.fu-berlin.de/en/v/mes6/documents/ proceedings/15072010.pdf

\section{Layer 3 - Books}

Anderson, C.R., \& Tate, W.F. (2008). Still separate, still unequal: Democratic access to mathematics in U.S. schools. In L.D. English (Ed.), Handbook of international research in mathematics education (2nd edn., pp. 299-318). New York, NY: Taylo \& Francis.

Christiansen, I.M. (2008). Some tensions in mathematics education for democracy. In B. Sriraman (Ed.), International perspectives on social justice in mathematics education (pp. 69-86). Missoula, MT: Information Age Publishing.

D'Ambrosio, U. (2003). The role of mathematics in building a democratic society. In B.L. Madison, \& L.A. Steen (Eds.), Quantitative literacy. Why numeracy matters for schools and colleges (pp. 235-238). Princeton, NJ: The National Council on Education and the Disciplines. Available from http://www.maa.org/ql/qltoc.html

Gellert, U., Jablonka, E., \& Keitel, C. (2001). Mathematical literacy and common sense in mathematics education. In B. Atweh., H. Forgasz, \& B. Nebres (Eds.) Sociocultural research on mathematics education: An international perspective (pp. 57-73). Mahwah, NJ: Lawrence Erlbaum.

Malloy, C.E. (2008). Looking throughout the world for democratic access to mathematics. In L.D. English (Ed.), Handbook of international research in mathematics education (2nd edn., pp. 20-31). New York, NY: Routledge.

Orrill, R. (2001). Mathematics, numeracy, and democracy. In L.A. Steen (Ed.), Mathematics and democracy. The case for quantitative literacy (pp. 8-20). Princeton, NJ: The National Council on Education and the Disciplines. Available from http://www.maa.org/ql/mathanddemocracy.htm

Skovsmose, O. (1994). Towards a philosophy of critical mathematics education. Dordrecht: Kluwer Academic Publishers.

Skovsmose, O., \& Valero, P. (2001). Breaking political neutrality: The critical engagement of mathematics education with democracy. In B. Atweh, H. Forgasz \& B. Nebres (Eds.), Sociocultural research on mathematics education: An international perspective (pp. 37-55). Mahwah, NJ: Lawrence Erlbaum.

Skovsmose, O., \& Valero, P. (2008). Democratic access to powerful mathematical ideas. In L.D. English (Ed.), Handbook of international research in mathematics education (2nd edn., pp. 415-438). New York, NY: Routledge. 